\title{
Conservation status and bio-ecology of Brycon orbignyanus (Characiformes: Bryconidae), an endemic fish species from the Paraná River basin (Brazil) threatened with extinction
}

\author{
Lívia Helena Tonella ${ }^{1}$, Rosa Maria Dias ${ }^{1,2}$, Oscar Barroso Vitorino Junior ${ }^{1}$, \\ Rosemara Fugi ${ }^{1,2}$ and Angelo Antonio Agostinho ${ }^{1,2}$
}

Brycon orbignyanus is an endemic species from La Plata basin whose stocks have been presenting significant reductions throughout the Paraná River. Brycon orbignyanus is categorized as an endangered species. This study evaluated aspects of the bio-ecology of this species that may be related to this threat, highlighting its distribution, abundance, and diet as well as the corresponding relationships between its recruitment and flood regimes. Data were obtained from different parts of the upper Paraná River (stretches free and regulated by dams) from 1986 to 2010 with more detailed data collected from the free remnant of this basin. The results indicate that no records for species exist at more than half of the sampling points located in dam-regulated sections of the Paraná River, whereas specimens were collected from $75 \%$ sites in the free plain remnant. We observed a remarkable effect of the hydrological regime on recruitment as well as distinct food demands during ontogenetic development, with adults almost exclusively consuming fruits and seeds, revealing that these individuals are supported by riparian vegetation. Thus, it is concluded that changes in the natural flood regime as well as riparian vegetation removal threaten B. orbignyanus populations in the Paraná River basin.

Keywords: Dam, Diet, Floodplain, Ontogeny, Recruitment.

Brycon orbignyanus é uma espécie endêmica da bacia do rio da Prata, cujos estoques vêm apresentando redução relevante em todo o rio Paraná, e está classificada como espécie ameaçada. Este estudo avaliou aspectos da bio-ecologia da espécie, relacionados a essa ameaça, destacando sua distribuição, abundância, dieta e relação entre o recrutamento e o regime de inundação. Os dados foram obtidos em diferentes partes da bacia do alto rio Paraná (trechos regulados por barragens e trechos livres) de 1986 a 2010, com detalhes no remanescente livre desse segmento (planície de inundação do alto rio Paraná). Os resultados indicam que não existem registros da espécie em mais da metade dos pontos de amostragem localizados nos trechos da bacia do rio Paraná reguladas por barragens, enquanto a espécie foi capturada em $75 \%$ dos locais amostrados na planície (remanescente livre de barragem). Foi observado um efeito marcante do regime hidrológico sobre o recrutamento de $B$. orbignyanus, bem como o uso de diferentes alimentos durante seu desenvolvimento ontogenético, com adultos consumindo quase exclusivamente frutos e sementes, revelando que esses indivíduos são sustentados pela vegetação ripária. Assim, conclui-se que mudanças no regime natural de inundação, bem como a remoção da vegetação ripária, ambas decorrentes de ações antropogênicas, ameaçam B. orbignyanus na bacia do rio Paraná.

Palavras-chave: Barragem, Dieta, Ontogenia, Planície de inundação, Recrutamento.

\section{Introduction}

Brycon orbignyanus (Valenciennes, 1850), common name piracanjuba, is a species of reophilic and migratory fish exclusively found in the Paraná River basin and in Uruguay (Lima, 2017), playing an important role as a commercially exploited natural resource (Lima, 2017) before joining the IUCN list (Agostinho et al., 2008). Over the last decades, piracanjuba stocks have been reduced across almost the entirety of its distribution area (Abilhoa, Duboc, 2004; Agostinho et al., 2008; Oliveira et al., 2017), resulting in relevant reductions in the Paraná River and in

${ }^{1}$ Programa de Pós-graduação em Ecologia de Ambientes Aquáticos Continentais, Universidade Estadual de Maringá, Av. Colombo, 5790, 87020-900 Maringá, PR, Brazil. (LHT) livia.tonella@gmail.com, Đhttps://orcid.org/0000-0001-9395-752X (corresponding author); (RMD) rmdias2003@yahoo.com.br, Dhttps://orcid.org/0000-0002-5898-0350; (OBV) jr.vitorino@gmail.com, @https://orcid. org/0000-0002-4783-4403

${ }^{2}$ Núcleo de Pesquisas em Limnologia, Ictiologia e Aquicultura, Universidade Estadual de Maringá, Av. Colombo, 5790, 87020-900 Maringá, PR, Brazil. (RF) rosemarafugi@gmail.com, Dhttps://orcid.org/0000-0002-7230-0817; (AAA) agostinhoaa@gmail.com, Dhttps://orcid. org/0000-0002-4707-9444 
their almost complete disappearance from upper and lower reaches of the Uruguay River (Agostinho et al., 2008; Lima, 2017; Oliveira et al., 2017).

The piracanjuba is currently on the official list of endangered species, listed as an endangered species (MMA, 2014). Various factors, including those related to riparian vegetation destruction, damming, pollution and the introduction of species, are considered to constitute the main threats to piracanjuba populations, with the former two have a particularly profound impact on the species (Agostinho et al., 2008). Riparian forest degradation is expected to negatively affect the piracanjuba's diet, which largely consists of terrestrial food (Agostinho et al., 2008), while outflow dam control is a permanent threat to piracanjuba stocks since the reproduction and recruitment of this species depend on the occurrence of intense and prolonged flooding periods (Oliveira et al., 2015). Although intensely regulated by a cascade of upstream reservoirs, the flood pulse remains as the main force that shapes the structure and functioning of communities in the upper Paraná River floodplain (Agostinho et al., 2000). However, since the formation of the Porto Primavera reservoir at the end of 1998, flood attributes, such as their periods, intensity levels and durations, have been intensely altered (Agostinho et al., 2005). Under these conditions, an absence of regular flooding negatively affects the entire reproductive process of migratory species while the larvae of species that can reproduce under these conditions do not reach nearby lagoons, which serve as essential biotopes for growth and feeding in early development stages, due to a lack of connectivity between floodplain environments (Agostinho et al., 2005; Suzuki et al., 2009).

Actions aimed at the conservation of endangered species have already been implemented by the Brazilian government, including Portaria 445/2014, which prohibits fishing for endangered species. However, the measure is ineffective due to the limited number of inspections conducted by executive agencies (Ashikaga et al., 2015). Attempts made to protect the species are also evidenced by induced spawning, raising and reservoir stocking programs promoted by hydroelectric concessionaires (Schork et al., 2013). However, the main factor limiting the efficacy of these management actions or the use of other attempted solutions relates to the precariousness of bio-ecological knowledge available on the species (Oliveira et al., 2017) and on threats to its conservation. Therefore, the long time series adopted and the approach proposed in this work are of fundamental importance and will subsidize management actions for the conservation of species threatened with extinction in accordance with commitments assumed by Brazil in signing and promulgating the Law of the Biodiversity Convention (Agenda 21 - CNUMAD, 1997).

Under this context, this study investigates piracanjuba's (Brycon orbignyanus) biological and ecological features, which may be related to such threats, with an emphasis on species distributions, abundance, diet variations, and the relationship between recruitment and attributes of the hydrological regime. Thus, the following objectives were sought: (i) to evaluate the conservation status of B. orbignyanus in the Paraná River basin, (ii) to evaluate abundance of the species found in the floodplain via spacetemporal analysis, (iii) to identify the relationship between this species' recruitment and flood attributes of the upper Paraná River floodplain and (iv) to identify ontogenetic diet variations that may indicate limitations to the species' population growth.

\section{Material and Methods}

The conservation status of $B$. orbignyanus populations was evaluated based on two aspects. First, species occurrence data for dam-regulated sections of the Paraná River basin made available in technical reports from hydroelectric concessionaires (CEMIG-IESA; CESP; Itaipu Binacional; FURNAS; DUKE Energy International; AES Tietê) for 1986 to 2006 and on 40 reservoirs of this basin (Fig. 1). In the reservoirs, fish were collected with gillnets of different mesh sizes. Due to variations between reservoirs in terms of gillnet number (with mesh sizes of 3.0 to $16.0 \mathrm{~cm}$ between knots), we used presence and absence data to avoid sampling bias. Second, data on B. orbignyanus catches of the upper Paraná River floodplain (Paraná, Baía and Ivinhema River subsystems) for 1986 to 2010 (Fig. 1).

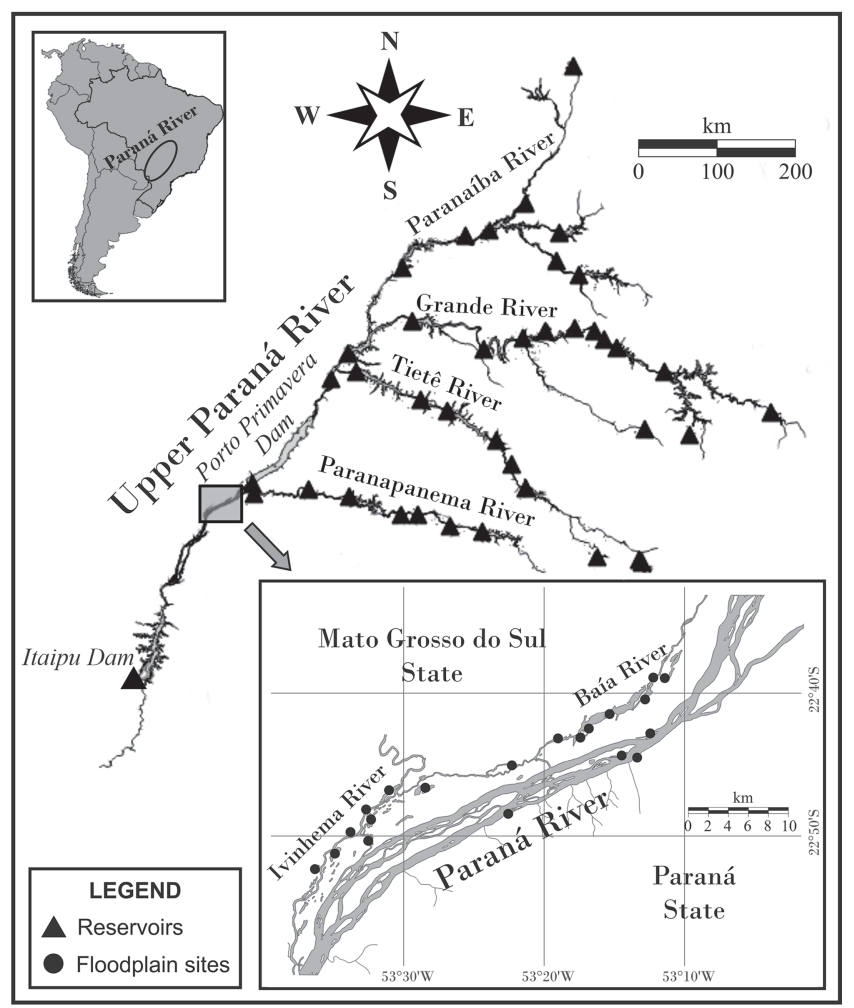

Fig. 1. The locations of reservoirs from which the Brycon orbignyanus occurrence was evaluated and sites sampled throughout the Upper Paraná River floodplain (the Paraná, Baía and Ivinhema River subsystems). 
The upper Paraná River floodplain is positioned between the Porto Primavera Dam and the Itaipu reservoir $(230 \mathrm{~km})$, forming the most extensive lotic stretch of the upper Paraná River in Brazilian territory (Fig. 1). It is noteworthy that although heavily regulated by upstream reservoirs, the lowlands still present a flood pulse pattern (Fig. S1). Fish were sampled on monthly basis from October 1986 to September 1988 and from March 1992 through February 1993; every two months from March 1994 through February 1995; and every three months from 2000 to 2010 . The sampling was carried out at 20 sampling stations located in floodplain lakes, channels, and river environments and distributed throughout the Paraná, Baía and Ivinhema River subsystems (Fig. 1). Gillnets of different mesh sizes were used to capture the fish. Fish were caught with a set of gillnets of different mesh sizes (with 3 to $16 \mathrm{~cm}$ of space between opposing nodes) that were submerged in water for 24 hours, and fish were removed in the morning, afternoon and evening.

After sampling, B. orbignyanus individuals were measured, weighed and eviscerated. Stomachs containing food were fixed in $4 \%$ formalin for diet analysis. Brycon orbignyanus abundance was expressed as CPUE (captures per unit of effort; individuals $/ 1000 \mathrm{~m}^{2}$ of gillnets over 24 hours) values transformed by $\log 10(\mathrm{x}+1)$. Spatial (Paraná, Baía and Ivinhema River subsystems) and temporal (yearly) differences in CPUE values were tested through an analysis of variance (two-way ANOVA) after determining and applying assumptions for their application. Tukey's post hoc test was used when significant differences were detected. The analysis of variance (two-way ANOVA) and Tukey tests were performed using Statistica 7.0 software (STATSOFT, 2005).

Paraná and Ivinhema River water level data were obtained through the Itaipu Binacional Hydrology Department. Flood regime attributes considered herein included interrupted (number of days the river exceeded water level thresholds during each hydrological cycle) and uninterrupted flood durations (days of continuous flooding). Flood durations were examined based on the recognized role of this variable in fish recruitment success (Gomes, Agostinho, 1997; Agostinho et al., 2004, Suzuki et al. 2009; Oliveira et al., 2015). For the Paraná River, the threshold hydrological level (river channel overflow) was measured as $4.5 \mathrm{~m}$ while values of above $2.75 \mathrm{~m}$ were considered for the Ivinhema River (Comunello et al., 2003).

Relationships between $B$. orbignyanus recruitment and the local flood regime were analyzed for the Paraná and Ivinhema Rivers. Recruitment was inferred based on young-of-year (YOY; < $23.0 \mathrm{~cm}$, Oliveira et al., 2015) CPUE values for October 1986 to September 1988, March 1992 to February 1995 and January 2000 to December 2010. A covariance analysis (ANCOVA) was applied to evaluate the relationship between YOY abundance (CPUE; captures per unit of effort; individuals $/ 1000 \mathrm{~m}^{2}$ of gillnets over 24 hours) transformed by $\log 10(\mathrm{x}+1)$ and flood duration (durations of interrupted and uninterrupted flooding). The slope models were adjusted separately when parallelism was not achieved (significant interactions). The YOY CPUE was applied as a dependent variable while the flood duration and rivers were used as co-variables and categorical variables, respectively. The covariance analysis (ANCOVA) was performed using the Statistica 7.0 program (STATSOFT, 2005).

The $B$. orbignyanus diet was evaluated for specimens collected in 2010 from sampling stations distributed throughout the Paraná, Baía and Ivinhema River subsystems. The stomach contents of 150 individuals were examined under a stereoscopic microscope, identified and expressed as volumes (water displacement in a graduated cylinder; Hyslop, 1980). The identified items were grouped into the following food categories: fish, aquatic invertebrates (Crustacea, Diptera and Ephemeroptera), terrestrial invertebrates (Araneae, Coleoptera, Hemiptera, Homoptera, Isoptera, Lepidoptera and Orthoptera), higher aquatic plants, and higher terrestrial plants (leaves, flowers, fruits and seeds). To verify ontogenetic diet variations, individuals were grouped YOYs $(n=109$; total length $<$ $23.0 \mathrm{~cm}$; Oliveira et al., 2015), juveniles $(n=28 ; 23.0$ - $31.6 \mathrm{~cm})$ or adults $(n=13 ;>31.6 \mathrm{~cm}$; Suzuki et al., 2004). Differences were tested through a Permutational Multivariate Variance Analysis (PERMANOVA) (Anderson et al., 2008). Post-hoc test pair-wise comparisons were drawn when significant dietary differences were detected. The PERMANOVA and Post-hoc tests were performed using PRIMER version 6.0 software. A significance of $P<$ 0.05 was applied for all tests.

\section{Results}

The surveys carried out from 1986 to 2006 in the upper Paraná River Basin reservoirs, during which at least one piracanjuba was observed in 16 of the 40 evaluated reservoirs (Tab. 1). It is noteworthy that piracanjuba occurred in only two of the 12 reservoirs evaluated in the Rio Grande Basin (the Água Vermelha and Volta Grande reservoirs). The species was observed in eight of the 24 large reservoirs located in the other evaluated tributaries (Paranaíba, Tietê and Paranapanema) (Tab. 1). However, it was also found in the four main channels of the Paraná River reservoirs and in long upstream lotic stretches and lateral tributaries (Tab. 1).

Regarding the remaining free stretch of the Paraná River floodplain, the species was observed in 16 of the 20 sampled sites (Tab. 2, but was absent in five of the 17 sampling years (in 2000 and from 2002-2005) (Fig. 2). The largest abundance was observed between 1992 and 1993 and in 2010 (Fig. 2), when intense and prolonged floods occurred (Fig. S1). Our evaluation of species abundance between sites and years via a two-way ANOVA did not identify any interactions between the factors $(F=1.06, P=$ 
Tab. 1. Presence of piracanjuba Brycon orbignyanus in reservoirs in the Upper Paraná River basin (+= present; - = absent). Source: Companhia Energética de São Paulo (CESP); Itaipu Binacional; Furnas Centrais Elétricas; Duke Energy Internacional; AES Tiête; Cemig-IESA.

\begin{tabular}{|c|c|c|c|c|c|}
\hline Reservoir & Basin & Status & Reservoir & Basin & Status \\
\hline ÁguaVermelha & Grande & + & Miranda & Paranaíba & + \\
\hline Caconde & Grande & - & Nova Ponte & Paranaíba & + \\
\hline Camargos & Grande & - & Paranoá & Paranaíba & - \\
\hline Estreito & Grande & - & São Simão & Paranaíba & - \\
\hline Furnas & Grande & - & Canoas I & Paranapanema & - \\
\hline Igarapava & Grande & - & Canoas II & Paranapanema & - \\
\hline Jaguara & Grande & - & Capivara & Paranapanema & - \\
\hline Machado Mineiro & Grande & - & Chavantes & Paranapanema & - \\
\hline Marimbondo & Grande & - & Jurumirim & Paranapanema & + \\
\hline Mascarenhas de Moraes & Grande & - & Rosana & Paranapanema & + \\
\hline Porto Colômbia & Grande & - & Taquaruçu & Paranapanema & + \\
\hline Volta Grande & Grande & + & Bariri & Tietê & - \\
\hline Ilha Solteira & Paraná & + & Barra Bonita & Tietê & - \\
\hline Itaipu & Paraná & + & Billings & Tietê & - \\
\hline Jupiá & Paraná & + & Guarapiranga & Tietê & - \\
\hline Porto Primavera & Paraná & + & Ibitinga & Tietê & + \\
\hline Cachoeira Dourada & Paranaíba & - & Ituporanga & Tietê & + \\
\hline Corumbá & Paranaíba & + & Nova Avanhandava & Tietê & + \\
\hline Emborcação & Paranaíba & - & Promissão & Tietê & - \\
\hline Itumbiara & Paranaíba & - & Três Irmãos & Tietê & + \\
\hline
\end{tabular}

Tab. 2. Abundance (Capture per unit effort - CPUE) of Brycon orbignyanus caught in the Upper Paraná River floodplain in different years (1986-2010) and subsystems (Paraná, Baía and Ivinhema). $0=$ Samplings occurred but no fish were caught. - = Sampling absent.

\begin{tabular}{|c|c|c|c|c|c|c|c|c|c|c|c|c|c|c|c|c|c|}
\hline \multirow{2}{*}{ Sites } & \multicolumn{17}{|c|}{ Years } \\
\hline & 1986 & 1987 & 1988 & 1992 & 1993 & 1994 & 2000 & 2001 & 2002 & 2003 & 2004 & 2005 & 2006 & 2007 & 2008 & 2009 & 2010 \\
\hline Paraná Subsystem & 0 & 0.26 & 0 & 7.68 & 3.12 & 0.98 & 0 & 0 & 0 & 0 & 0 & 0 & 0 & 0 & 0 & 0 & 5.6 \\
\hline Paraná River & 0 & 0.26 & 0 & 7.68 & 2.95 & 0.98 & 0 & 0 & 0 & 0 & 0 & 0 & 0 & 0 & 0 & 0 & 3.92 \\
\hline Pau Véio Lake & - & - & - & - & - & - & 0 & 0 & 0 & 0 & 0 & 0 & 0 & 0 & 0 & 0 & 0.98 \\
\hline Garças Lake & - & - & - & - & - & - & 0 & 0 & 0 & 0 & 0 & 0 & 0 & 0 & 0 & 0 & 1.96 \\
\hline Cortado Channel & - & - & - & 3.54 & 3.28 & 0.98 & 0 & 0 & - & - & - & - & - & - & - & - & 25.49 \\
\hline Baía Subsystem & 1.08 & 0.08 & 0.51 & 8.27 & 0.33 & 0.74 & 0 & 0 & 0 & 0 & 0 & 0 & 0 & 0 & 0 & 0.98 & 4.81 \\
\hline Baia River & 0 & 0 & 1.21 & 0.51 & 0.66 & 1.48 & 0 & 0 & 0 & 0 & 0 & 0 & 0 & 0 & 0 & 0.98 & 0 \\
\hline Curutuba Channel & 0 & 0 & 0 & - & - & - & 0 & 0 & - & - & - & - & - & - & - & - & 7.84 \\
\hline Fechada Lake & 6.14 & 0.52 & 0.03 & - & - & - & 0 & 0 & 0 & 0 & 0 & 0 & 0 & 0 & 0 & 0 & 6.86 \\
\hline Guaraná Lake & 0 & 0 & 0 & 0 & 0 & 0 & 0 & 0 & 0 & 0 & 0 & 0 & 0 & 0 & 0 & 0 & 0 \\
\hline Pousada Lake & 0 & 0 & 0 & - & - & - & 0 & 0 & - & - & - & - & - & - & - & - & 0 \\
\hline Baia Channel & - & - & - & - & - & - & 0 & 0 & - & - & - & - & - & - & - & - & 0 \\
\hline Gavião Lake & - & - & - & - & - & - & 0 & 0 & - & - & - & - & - & - & - & - & 5.88 \\
\hline Onça Lake & - & - & - & - & - & - & 0 & 0 & - & - & - & - & - & - & - & - & 7.84 \\
\hline Ivinhema Subsystem & 0.27 & 0.84 & 0.27 & 8.27 & 1.8 & 0.25 & 0 & 0.74 & 0 & 0 & 0 & 0 & 0.65 & 1.96 & 0.98 & 0.98 & 20.14 \\
\hline Ivinhema River & 0.79 & 1.53 & 0.35 & 7.87 & 0 & 0.49 & 0 & 0 & 0 & 0 & 0 & 0 & 0.98 & 4.9 & 0 & 0.98 & 30.39 \\
\hline Ipoitã Channel & 0 & 0.77 & 0.69 & - & - & - & 0 & 0 & - & - & - & - & - & - & - & - & 49.02 \\
\hline Patos Lake & 0 & 0.38 & 0 & 8.66 & 3.61 & 0 & 0 & 0 & 0 & 0 & 0 & 0 & 0 & 0 & 0 & 0 & 2.94 \\
\hline Ventura Lake & - & - & - & - & - & - & 0 & 5.88 & 0 & 0 & 0 & 0 & 0.98 & 0.98 & 1.96 & 1.96 & 30.39 \\
\hline Peroba Lake & - & - & - & - & - & - & 0 & 0 & - & - & - & - & - & - & - & - & 1.76 \\
\hline Zé do Paco Lake & - & - & - & - & - & - & 0 & 0 & - & - & - & - & - & - & - & - & 17.65 \\
\hline Raimundo Lake & - & - & - & - & - & - & 0 & 0 & - & - & - & - & - & - & - & - & 19.61 \\
\hline Sumida Lake & - & - & - & - & - & - & 0 & 0 & - & - & - & - & - & - & - & - & 7.84 \\
\hline
\end{tabular}


0.37). Significant differences in B. orbignyanus abundance were found between the sites $(F=3.18, P=0.04)$ and years $(F=13.85, P<0.01)$. Abundance differed between the Ivinhema and Paraná Rivers $(P=0.04)$, and the species was more captured from the Ivinhema River (Fig. 2). No significant differences in abundance between the Paraná and Baía Rivers $(P=0.81)$ or between the Baía and Ivinhema Rivers $(P=0.16)$ were observed. A significant difference between abundance caught in 2010 and in the other evaluated years was detected $(P<0.01)$ with the highest piracanjuba abundance observed in 2010 (Fig. 2).

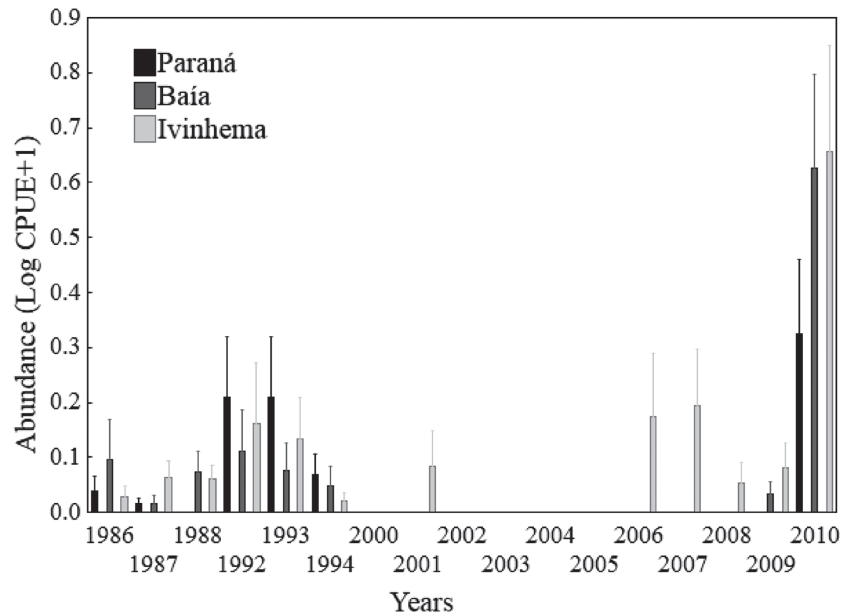

Fig. 2. Abundance (captures per unit of effort - CPUE) of Brycon orbignyanus observed in the Upper Paraná River floodplain in different years (1986 to 1988, 1992 to 1994 and 2000 to 2010) and subsystems (Paraná, Baía and Ivinhema).

Regarding plain biotopes, the most widely sampled specimens were YOYs $(69.8 \%$ of the catches) and juveniles, which together represented $93 \%$ of the catches, while adults were very rare even during the most favorable recruitment years (Tab. S1). The relationship between the main hydrological attributes and recruitment based on YOY abundance shows that recruitment was successful only in years with long flooding periods (Fig. 3a,b). Thus, relevant recruitment values were found only for years with flood durations of over 60 days in both Paraná (threshold $=4.5 \mathrm{~m})$ and Ivinheima $(2.75 \mathrm{~m})$ (Fig. 3a; Fig. S1). The number of YOYs captured was also found to be relevant for less enduring but uninterrupted flooding events (Fig. 3b; Fig. S1). The results of the covariance analysis (ANCOVA) indicate that YOY CPUE was positively related to flood duration attributes for both rivers evaluated (Tab. 3).

The piracanjuba's diet was found to be composed largely of fish and higher terrestrial plants (Fig. 4). The PERMANOVA reveals significant ontogenetic dietary differences (pseudo- $F=7.20, P=0.001$ ) across the three piracanjuba development stages: YOYs and juveniles $(t$ $=2.42, P=0.002)$, juveniles and adults $(t=1.73, P=$ $0.025)$, and YOYs and adults $(t=3.13, P=0.001)$. YOYs consumed larger amounts of fish $(45.8 \%$ of their diet $)$ and higher terrestrial plants (31.4\%), juvenile mainly consumed higher terrestrial plants (62.4\% - mainly Inga sp., Cecropia sp. and Mauritia sp. fruits and seeds) and fish to a lesser degree (17.1\%), and adults almost exclusively consumed terrestrial higher plants $(98.4 \%$ - mainly Inga sp., Cecropia sp. and Mauritia sp. fruits and seeds) (Fig. $4)$.
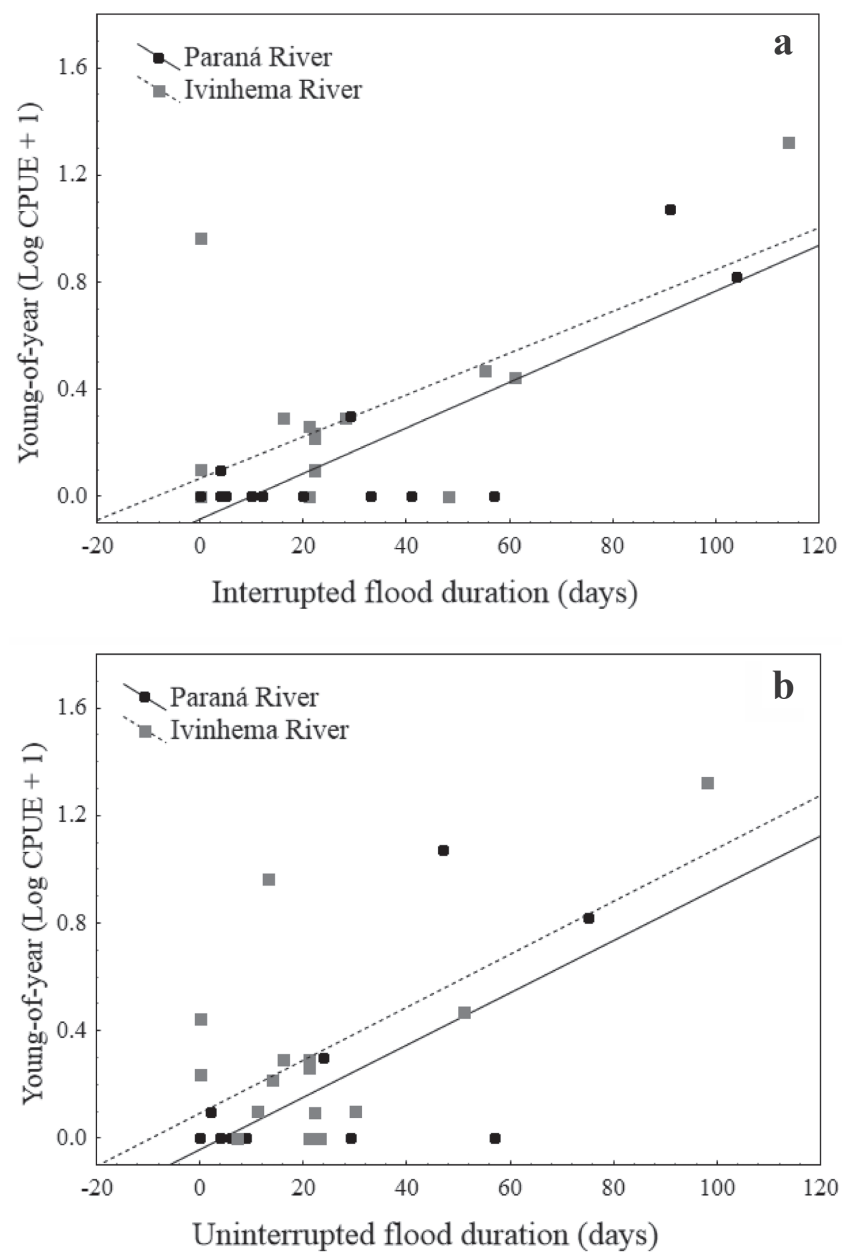

Fig. 3. Relationships between YOY abundance (CPUE) of Brycon orbignyanus and hydrological attributes observed in the Paraná and Ivinhema subsystems. a. Interrupted flood duration (days) (>4.5 m Paraná River and $>2.75 \mathrm{~m}$ Ivinhema River), b. Uninterrupted flood duration (days).

Tab. 3. Results of covariance analysis (ANCOVA) of piracanjuba Brycon orbignyanus YOY abundance (CPUE) and hydrological attributes (durations of interrupted and uninterrupted flood periods). $\mathrm{P}<0.05$ represents significant relation. $\beta=$ Standardized Slops.

\begin{tabular}{lcccc}
\hline \multicolumn{1}{c}{ Factors } & $\mathrm{MS}$ & $\mathrm{F}$ & $\mathrm{P}$ & $\beta$ \\
\hline Interrupted flood duration *Rivers & 168.99 & 28.87 & $<0.01$ & - \\
Paraná & - & - & $<0.01$ & 0.07 \\
Ivinhema & - & - & $<0.01$ & 0.15 \\
Uninterrupted flood duration & 253.81 & 25.63 & $<0.01$ & 0.13 \\
Rivers & 6.42 & 0.65 & 0.43 & - \\
\hline
\end{tabular}




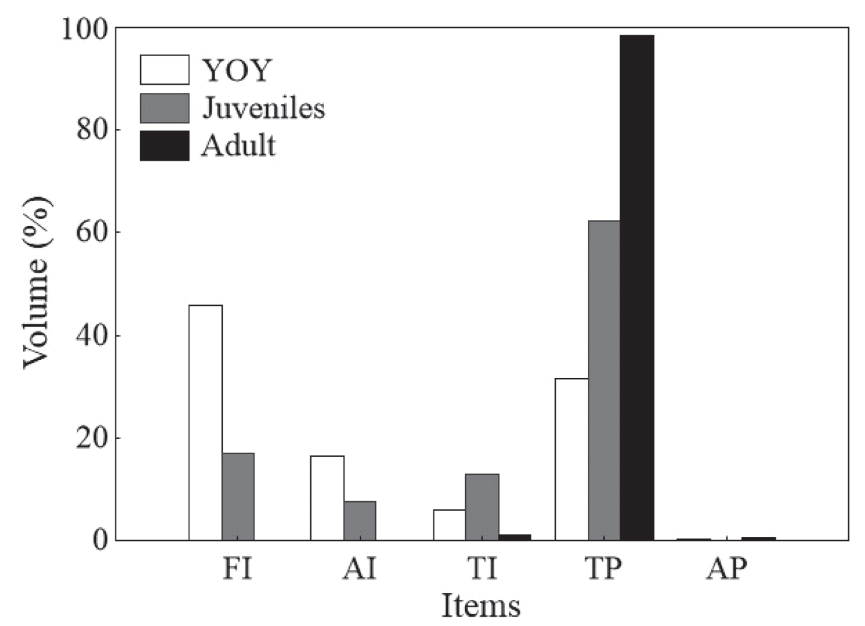

Fig. 4. Ontogenetic variations in the diet of Brycon orbignyanus in the Upper Paraná River floodplain. FI = fish; $\mathrm{AI}=$ aquatic invertebrates; $\mathrm{TI}=$ terrestrial invertebrates; $\mathrm{TP}$ $=$ terrestrial plants; $\mathrm{AP}=$ aquatic plants.

\section{Discussion}

This study confirms that the piracanjuba has almost disappeared from upper Paraná River tributaries with reservoir cascades (the Paranapanema, Tietê and Grande Rivers) and that its presence in some of these areas may be attributable to stocking programs (CESP, 2000). In the free stretches of this basin, the species is rare after prolonged periods of drought, making it abundant in years of flooding (Oliveira et al., 2015). The fact that the species is rarely found in reservoirs and that the success of its recruitment from dam-free areas depends on the occurrence of extraordinary flooding events (not regulated by upstream reservoirs) suggests that the interception of migratory routes and flood regulation through damming are the main causes of its nearly full disappearance from the upper Paraná River.

The disappearance of this species from upper reaches of the Paraná River Basin, including the Rio Grande, was recorded more than 40 years ago (Godoy, 1975). In upper reaches of the Uruguay River also transformed by damming, the species has been recorded as virtually extinct for 20 years (Zaniboni-Filho, Schulz, 2003), and its subsequent reappearance is attributed to stocking programs (Schork et al., 2012, 2013). However, the results obtained from the present study show that the capture of adult individuals has been reduced even in dam-free areas, including the $230-\mathrm{km}$ stretch of the Paraná River from the Porto Primavera Dam to the Itaipu reservoir. The results presented here for this region indicate that prolonged flooding periods result in high abundance of YOYs, reinforcing the importance of these hydrological regime attributes as key factors for the species' conservation in Neotropical rivers (Cooke et al., 2012; Alves et al., 2013; Oliveira et al., 2015). The success of piracanjuba recruitment in this region is associated, in addition to flood pulse, to large tributaries of the Paraná River (the Iguatemi, Ivinhema, Piquiri and Ivaí Rivers) not regulated by dams (Affonso et al., 2015) and to three conservation units (Parque Nacional de Ilha Grande, Parque Estadual do Ivinhema, and Área de Proteção Ambiental das Ilhas e Várzeas do Rio Paraná). These tributaries still maintain natural characteristics related to the flood regime, providing spawning sites and initial development areas for migratory fish (Bialetzki et al., 2005; Reynalte-Tataje et al., 2013; Silva et al., 2017). Long periods of flooding allow juveniles to reach sizes less susceptible to predation when they leave structured environments during water retraction and occupy main river channels (Agostinho et al., 2008; Alves et al., 2013). Among the 11 large migratory species found in the upper Paraná River Basin, the piracanjuba is considered to be the most dependent on prolonged flooding periods and to be the most sensitive to delays in their onset (Oliveira et al., 2015).

The piracanjuba's diet is marked by ontogenetic variations, and during the species' development a decline in the consumption of aquatic resources (fish) and a marked increase in the consumption of higher terrestrial plants were observed with adults almost exclusively consuming fruits and seeds, revealing that these individuals are essentially supported by resources provided by riparian vegetation. Dependence on food of terrestrial origin (mainly plants) has been reported by other researchers, such as by Godoy (1975) in reference to the Mogi-Guaçú River and by Reis et al. (2003) in reference to the Uruguay River, and it has also been reported in relation to other Brycon species found in other basins, including $B$. amazonicus (Agassiz, 1829) in the Solimões River (Leite, 2004); B. orthotaenia Günther, 1864 in the São Francisco River (Alvim, Peret, 2004; Nunes et al., 2015); B. falcatus Müller \& Troschel 1844, B. gouldingi Lima, 2004 and $B$. nattereri Günther, 1864 in the Tocantins River (Albrecht et al., 2009; Vitorino-Jr et al., 2014) and B. opalinus (Cuvier, 1819) found along Brazilian coastal basins (Gomiero et al., 2008). These results, and the revision of the genus by Lima (2017), highlight the importance of riparian vegetation for several Brycon species, and this peculiarity renders these species even more susceptible to changes in its biotopes.

The marked changes observed in B. orbignyanus diets throughout the life cycle may be a cause of notable declines in their population observed in the upper Paraná River floodplain as evidenced by the large number of juveniles found in years of heavy flooding and by the small number of adults observed in subsequent periods. Remarkable ontogenetic changes in the piracanjuba's diet, which is characterized by an extreme dependence on fruits and seeds during adulthood, render this species extremely vulnerable and especially in the Paraná River, where riparian vegetation is significantly altered in relation to its original phyto-physiognomy (Corradini et al., 2006). Native plants provide fruit for fish throughout the year. However, as riparian vegetation within the plain is under the influence of constant anthropogenic disturbances, such as periodic fires, partial removal and degradation by cattle trampling (Campos, Souza, 2002; Souza et al., 2004), vegetation succession processes lead to a predominance of early stage species, requiring more time for tree establishment (Campos, Souza, 2002; Pott et al., 2014) and, consequently, 
greater diversity in the supply of fish food resources. In fact, fruits and seeds of pioneer species such as Inga and Cecropia are currently heavily consumed by piracanjuba. Floods readily provide terrestrial food resources to fish (Goulding et al., 1988; Walker et al., 2013; Quirino et al., 2017). Thus, the degradation of riparian vegetation coupled with decreased flood intensity levels and amplitudes especially affect species that depend on inputs of terrestrial food for the maintenance of species such as the piracanjuba.

In view of the obtained results, it has been evidenced herein that the preservation of riparian vegetation is essential for the maintenance of the piracanjuba population stratum, which feeds almost exclusively on fruits and seeds. In addition, as a species that migrates long distances (Oliveira et al., 2015), the piracanjuba may act as dispersing agent for seeds of riparian vegetation in the same way as suggested for other Brycon species (i.e., Goulding, 1980; Horn, 1997; Reys et al., 2009), facilitating the support and regeneration of riparian forests. In this case, the conservation of riparian vegetation is intrinsically related to the maintenance of the ichthyofaunistic biodiversity of the floodplain (Pusey, Arthington, 2003), and the maintenance of piracanjuba populations at the same time constitutes a facet of conservation strategies developed for this type of vegetation. Under this context, conservation units established in the dam-free segment of the Upper Paraná River play an essential role in biodiversity conservation (Agostinho et al., 2005). In fact, a marked increase in piracanjuba catches over the last years of the study period was observed and may be related to the creation and implementation of Parque Estadual do Rio Ivinhema (SEMA, 2001) with 73,345.15 hectares of extension (Decree 9.278, December 17, 1998). However, as is typically expected for large migrating populations, this species requires a wide area to complete its life cycle, exceeding the limits of this conservation unit.

Brycon orbignyanus' biological and ecological characteristics allow for the use of this species as an indicator of aquatic ecosystem biotic integrity, given its high sensitivity to hydrological. Thus, conservation initiatives aimed at protecting the species' habitats (maintenance and restoration) and restrictions on engineering projects that affect flood pulses may have direct effects on other species that share $B$. orbignyanus occurrence areas, indicating that conservation efforts have positive effects on other migratory species and on riparian vegetation conservation.

\section{Acknowledgments}

We thank the Núcleo de Pesquisas em Limnologia, Ictiologia e Aquicultura (Nupélia/UEM), the Programa de Pós-Graduação em Ecologia de Ambientes Aquáticos Continentais (PEA/UEM) and the Programa de Pesquisas Ecológicas de Longa Duração (PELD/CNPq). L. H. Tonella, R. M. Dias, O. B. Vitorino Junior and A. A. Agostinho acknowledge the Brazilian Council of Research (CNPq and CAPES) for providing grants. The authors thank two anonymous reviewers for their helpful comments.

\section{References}

Abilhoa V, Duboc LF. Peixes - Água doce. In: Mikich SB, Bérnils RS, editors. Livro vermelho da fauna ameaçada no estado do Paraná. Curitiba: Instituto Ambiental do Paraná; 2004. p.579-677.

Affonso IP, Azevedo RF, Santos NLC, Dias RM, Agostinho AA, Gomes LC. Pulling the plug: strategies to preclude expansion of dams in Brazilian rivers with high-priority for conservation. Nat Conserv. 2015; 13:199-203. https://doi.org/10.1016/j. ncon.2015.11.008

Agostinho AA, Gomes LC, Veríssimo S, Okada EK. Flood regime, dam regulation and fish in the Upper Paraná river: effects on assemblage attributes, reproduction and recruitment. Rev Fish Biol Fish. 2004; 14:11-19. https://doi.org/10.1007/s11160004-3551-y

Agostinho AA, Thomaz SM, Gomes LC. Conservation of the biodiversity of Brazil's waters. Conserv Biol. 2005; 19(3):64652. https://doi.org/10.1111/j.1523-1739.2005.00701.x

Agostinho AA, Thomaz SM, Minte-Vera CV, Winemiller KO. Biodiversity in the high Paraná river floodplain. In: Gopal B, Junk WJ, Davis, JA, editors. Biodiversity in wetlands: assessment, function and conservation. Leiden: Backhuys; 2000. p.89-118.

Agostinho AA, Zaniboni-Filho E, Lima FCT. Brycon orbignyanus (Valenciennes 1850). In: Machado ABM, Drummond GM, Paglia AP, editors. Livro vermelho da fauna brasileira ameaçada de extinção. Brasília: MMA, Belo Horizonte: Fundação Biodiversitas; 2008. p.54-56.

Albrecht MP, Caramaschi EP, Horn MH. Population responses of two omnivorous fish species to impoundment of a Brazilian tropical river. Hydrobiologia. 2009; 627:181-93. https://doi. org/10.1007/s10750-009-9727-7

Alves DC, Minte-Vera CV, Agostinho AA, Okada EK, Vasconcelos LP. Hydrological attributes and rheophilic freshwater fish: stock assessment. Rev Fish Biol Fish. 2013; 23(3):375-94. http:// dx.doi.org/10.1007/s11160-012-9298-y

Alvim MCC, Peret AC. Food resources sustaining the fish fauna in a section of the upper São Francisco River in Três Marias, MG, Brazil. Braz J Biol. 2004; 64(2):195-202. http://dx.doi. org/10.1590/S1519-69842004000200003

Anderson MJ, Gorley RN, Clarke KR. PERMANOVA + for PRIMER: Guide to software and statistical methods. England: Plymouth, PRIMER-E; 2008.

Ashikaga FY, Orsi ML, Oliveira C, Senhorini JA, Foresti F. The endangered species Brycon orbignyanus: genetic analysis and definition of priority areas for conservation. Environ Biol Fish. 2015; 98(7):1845-55. http://dx.doi.org/10.1007/s10641015-0402-8

Bialetzki A, Nakatani K, Sanches PV, Baumgartner G, Gomes LC. Larval fish assemblage in the Baía River (Mato Grosso do Sul State, Brazil): temporal and spatial patterns. Environ Biol Fish. 2005; 73(1):37-47. http://dx.doi.org/10.1007/ s10641-004-3795-3

Campos JB, Souza MC. Arboreous vegetation of an alluvial riparian forest and their soil relations: Porto Rico Island, Paraná River, Brazil. Braz Arch Biol Technol. 2002; 45(2):137-49. http:// dx.doi.org/10.1590/S1516-89132002000200004

Companhia Energética de São Paulo (CESP). Programa de manejo pesqueiro. São Paulo: CESP; 2000.

Conferência das Nações Unidas sobre Meio Ambiente e Desenvolvimento (CNUMAD). Agenda 21. São Paulo: Secretaria do Estado do Meio Ambiente; 1997.

Comunello E, Souza Filho EE, Rocha PC, Nanni MR. Dinâmica de inundação de áreas sazonalmente alagáveis na planície aluvial do alto rio Paraná: estudo preliminar. Anais do $11^{\circ}$ Simpósio 
brasileiro de sensoriamento remoto. São José dos Campos: INPE; 2003. p.2459-66.

Cooke SJ, Paukert C, Hogan Z. Endangered river fish: factors hindering conservation and restoration. Endanger Species Res. 2012; 17:179-91. https://doi.org/10.3354/esr00426.

Corradini FA, Fachini MP, Stevaux JC. Controle geomorfológico da distribuição da vegetação ripária do rio Paraná: Parte I Unidades geomórficas da planície de inundação. Revista UnGGeociências. 2006; 5(1):13-21.

Godoy MP. Peixes do Brasil, Subordem Characoidei, bacia do rio Mogi Guassu. Piracicaba: Franciscana; 1975.

Gomes LC, Agostinho AA. Influence of the flooding regime on the nutritional state and juvenile recruitment of the curimba, Prochilodus scrofa, Steindachner, in upper Paraná river, Brazil. Fish Manag Ecol. 1997; 4:263-74.

Gomiero LM, Manzatto AG, Braga FMS. The role of riverine forests for food supply for the omnivorous fish Brycon opalinus Cuvier, 1819 (Characidae) in the Serra do Mar, Southeast Brazil. Braz J Biol. 2008; 68(2):321-28. http://dx.doi.org/10.1590/S151969842008000200013

Goulding M. The fishes and the forest. Explorations in Amazonian natural history. Berkeley: University of California Press; 1980.

Goulding M, Carvalho ML, Ferreira EG. Rio Negro: rich life in poor water. The Hague: SBP Academic Publisher; 1988.

Horn $\mathrm{MH}$. Evidence for dispersal of fig seeds by the fruit-eating characid fish Brycon guatemalensis Regan in a Costa Rican tropical rain forest. Oecologia. 1997; 109(2):259-264. http:// dx.doi.org/10.1007/s004420050081

Hyslop EJ. Stomach contents analysis: a review of methods and their application. J Fish Biol. 1980; 17:411-29. http://doi. org/10.1111/j.1095-8649.1980.tb02775.x.

Leite RG. A alimentação de juvenis de matrinxã, Brycon amazonicus (Pisces, Characidae), em áreas inundadas da Ilha de Marchantaria, Amazonas, Brasil. Acta Amazon. 2004; 34(4):661-64.

Lima FCT. A revision of the cis-andean species of the genus Brycon Müller \& Troschel (Characiformes: Characidae). Zootaxa. 2017; 4222(1):1-189.

Ministério do Meio Ambiente (MMA). Portaria $n^{\circ} 445$, de 17 de dezembro de 2014. Diário Oficial da União, Seção 1, 245, 18/12/2014:126.

Nunes DMF, Magalhães ALB, Weber AA, Gomes RZ, Normando FT, Santiago KB, Rizzo E, Bazzoli N. Influence of a large dam and importance of an undammed tributary on the reproductive ecology of the threatened fish matrinxã Brycon orthotaenia Günther, 1864 (Characiformes: Bryconidae) in southeastern Brazil. Neotrop Ichthyol. 2015; 13(2):317-24. https://doi. org/10.1590/1982-0224-20140084

Oliveira AG, Suzuki HI, Gomes LC, Agostinho AA. Interspecific variation in migratory fish recruitment in the Upper Paraná River: effects of the duration and timing of floods. Environ Biol Fish. 2015; 98(5):1327-37. https://doi.org/10.1007/s10641-0140361-5

Oliveira DJ, Ashikaga FY, Foresti F, Senhorini JA. Conservation status of the "Piracanjuba" Brycon orbignyanus (Valenciennes, 1850) (Characiformes, Bryconidae): basis for management programs. Biodiversidade Brasileira. 2017; 7(1):18-33.

Pott A, Silva JSV, Gomes, EL. Características da bacia hidrográfica do Ivinhema. Revista GeoPantanal. 2014; 9(16):109-24.

Pusey BJ, Arthington AH. Importance of the riparian zone to the conservation and management of freshwater fish: a review. Mar Freshwater Res. 2003; 54:1-6. https://doi.org/10.1071/MF02041

Quirino BA, Carniatto N, Guglielmetti R, Fugi R. Changes in diet and niche breadth of a small fish species in response to the flood pulse in a Neotropical floodplain lake. Limnologica. 2017; 62:126-31. https://doi.org/10.1016/j.limno.2016.10.005
Reis RE, Lucena ZMS, Lucena CAS, Malabarba LR. Peixes. In: Fontana CS, Bencke GA, Reis RE, editors. Livro vermelho da fauna ameaçada de extinção no Rio Grande do Sul. Porto Alegre: Edipucrs; 2003. p.117-45.

Reynalte-Tataje DA, Agostinho AA, Bialetzki A. Temporal and spatial distributions of the fish larval assemblages of the Ivinheima River sub-basin (Brazil). Environ Biol Fish. 2013; 96(7):811-22. https://doi.org/10.1007/s10641-012-0073-7.

Reys P, Sabino J, Galetti M. Frugivory by the fish Brycon hilarii (Characidae) in western Brazil. Acta Oecol. 2009; 35:136-41. https://doi.org/10.1016/j.actao.2008.09.007.

Schork G, Hermes-Silva S, Beux LF, Zaniboni-Filho E, Nuñer APO. Diagnóstico da pesca artesanal na usina hidrelétrica de Machadinho, alto rio Uruguai - Brasil. Bol Inst Pesca. 2012; 38(2):97-108. https://www.pesca.sp.gov.br/38_2_97-108.pdf

Schork G, Hermes-Silva S, Zaniboni-Filho E. Analysis of fishing activity in the Itá reservoir, Upper Uruguay River, in the period 2004-2009. Braz J Biol. 2013; 73(3):559-71. http://dx.doi. org/10.1590/S1519-69842013000300014

Secretaria de Estado do Meio Ambiente (SEMA). Decreto 9.278, de 17 de dezembro de 1998. Decreto de criação do Parque das Várzeas do Rio Ivinhema. Campo Grande: Diário Oficial de Mato Grosso do Sul; 2001.

Silva CB, Dias JD, Bialetzki A. Fish larvae diversity in a conservation area of a Neotropical floodplain: influence of temporal and spatial scales. Hydrobiologia. 2017; 787:141-52. http://dx.doi. org/10.1007/s10750-016-2953-x

Souza MC, Romagnolo MB, Kita KK. Riparian vegetation: ecotones and plant communities. In: Thomaz SM, Agostinho AA, Hahn NS, editors. The upper Paraná River and its floodplain: physical aspects, ecology and conservation. Leiden: Backhuis Publishers; 2004. p.353-67.

Statsoft, Inc. STATISTICA [Data Analysis Software System], version 7.1. 2005. [Internet] www.statsoft.com

Suzuki HI, Agostinho AA, Bailly D, Gimenes MF, Júlio-Jr HF, Gomes LC. Inter-annual variations in the abundance of youngof-the-year of migratory fishes in the Upper Paraná River floodplain: relations with hydrographic attributes. Braz J Biol. 2009; 69(2):649-60. http://dx.doi.org/10.1590/S151969842009000300019.

Suzuki HI, Vazzoler AEAM, Marques EE, Lizama MAP. Reproductive ecology of fish assemblages. In: Thomaz SM, Agostinho AA, Hahn NS, editors. The upper Paraná River and its floodplain: physical aspects, ecology and conservation. Leinden: Backhuis Publishers; 2004. p.271-91.

Vitorino-Jr OB, Lopes KS, Pelicice FM. Abundance and length structure of Brycon nattereri (Osteichthyes, Bryconidae), an endangered fish species in central Brazil. Acta Sci Biol Sci. 2014; 36(4):421-25. http://dx.doi.org/10.4025/actascibiolsci. v36i4.23857

Walker RH, Kluender ER, Inebnit TE, Adams SR. Differences in diet and feeding ecology of similar-sized spotted (Lepisosteus oculatus) and shortnose (Lepisosteus plastomus) gars during flooding of a south-eastern US river. Ecol Freshw Fish. 2013; 22:617-25. https://doi.org/10.1111/eff.12066

Zaniboni-Filho E, Schulz UH. Migratory fishes of the Uruguay River. In: Carolsfeld J, Harvey B, Ross C, Baer A, editors. Ottawa: The World Bank, International Development Research Centre; 2003. p.135-68. 